\title{
Blood Plasma Mineral Profile and Qualitative Indicators of the Eggshell in Laying Hens in Different Housing Systems
}

\author{
Aleš Pavlík ${ }^{1}$, Martina Lichovníková2 ${ }^{2}$ Pavel Jelínek ${ }^{1}$ \\ ${ }^{1}$ Department of Animal Morphology, Physiology and Genetics, Mendel University of Agriculture and Forestry, \\ Brno, Czech Republic \\ ${ }^{2}$ Department of Animal Breeding, Mendel University of Agriculture and Forestry, Brno, Czech Republic
}

Received November 10, 2008

Accepted March 9, 2009

\begin{abstract}
The aim of this study was to compare the blood plasma mineral profile $(\mathrm{Ca}, \mathrm{P}, \mathrm{K}, \mathrm{Mg}, \mathrm{Zn}$, $\mathrm{Cu}$ and $\mathrm{Se}$ ) and egg-shell quality (eggshell weight, eggshell breaking strength and thickness) of laying hens housed in three different housing systems (traditional cage system, enriched cage system and deep litter system). In each housing system, 12 ISA Brown laying hens were observed during the laying period from week 22 to 75 of age. The effect $(p<0.05$ and $p<0.01)$ of age and/or phase of the laying cycle on all mineral concentrations was determined. Eggshell breaking strength decreased $(p<0.001)$ with the age of birds. The results of this study indicate that the housing systems compared had no significant effect on the blood plasma mineral profile of laying hens under study and the values were within the physiological range. However, a significant effect of housing system on eggshell breaking strength and eggshell weight was found. Improved eggshell quality was obtained in most periods of the laying cycle in the enriched cage systems.
\end{abstract}

Blood minerals, egg-shell quality, standard cage, enriched cage, deep litter floor

Passage of the Council Directive 1999/74/EC has resulted in the replacement of traditional cages with enriched cages, litter technologies or aviaries to improve the welfare of laying hens. The shell quality remains one of the most important issues for the technology of further egg handling (Ledvinka et al. 2000). However, some authors pointed out that there are differences in eggshell quality and proportion of cracked eggs between different housing systems (Abrahamsson et al. 1995; Abrahamsson and Tauson 1997; Wall and Tauson 2002). Shell quality can be influenced by many factors including mineral nutrition. Calcium, magnesium and phosphorus are major inorganic constituents of avian eggshells (Cusack et al. 2003). Simons (1976) found small amounts of potassium, copper and zinc in the palisade layer of the eggshell. The presence of sodium, potassium, magnesium, zinc, and copper was confirmed also in the shell membranes (Wedral et al. 1974). The importance of minerals is reflected in changes of arrangement pattern of shell membrane fibres in relation to the structural composition of the eggshell, for example when using copper- and magnesium-deficient diets (Leach and Gross 1983). Traces of magnesium, potassium, copper and zinc were also found in the egg cuticle. Plasma mineral concentrations during the laying period can be influenced by many factors; such as laying rate and energy requirements (Suchý et al. 2001), partial quantitative feed restriction (Sahin and Kucuk 2001), mineral supplements (Eren et al. 2004), ambient temperature (Siegel 1995; Donoghue et al. 1990; Ching 1992; Belay and Teeter 1993; Večerek et al. 2002), production type (Suchý et al. 2004), age of hens (Cerolini et al. 1990; Gyenis et al. 2006), stress (Beisel 1982; Combs and Combs 1984; Tufft and Nockles 1991; Klasing 1998), exposure to heavy metals (Zralý et al. 2008), etc.

With regard to differences in eggshell quality between different housing systems we presumed also differences in the blood plasma mineral profile of hens. The objective of

Phone: + 420545133148

Fax. +420545133176

E-mail: pavlik@mendelu.cz

http://www.vfu.cz/acta-vet/actavet.htm 
this study was to investigate the effects of different housing systems on plasma mineral profile in relation to eggshell quality. To our knowledge, studies comparing blood plasma mineral profile indicators among hens kept in these three systems have not yet been performed.

\section{Materials and Methods}

The experiments were performed in ISA BROWN pullets, kept in a hall with deep litter technology. The available area, complete diet, light-dark (L : D) cycle, temperature of housing, relative humidity of air changed according to technological instructions for ISA BROWN pullets. During the rearing period standard vaccinations were performed. At the age of 15 weeks, the animals were randomly divided into 3 of the following breeding systems:

Traditional cage housing system (S) - four-floor, total (available) area $550 \mathrm{~cm}^{2} /$ bird (2 birds kept on $1120 \mathrm{~cm}^{2}$ $-32 \times 35 \times 45 \mathrm{~cm}$ ), 2 nipple drinkers, belt feeder $15 \mathrm{~cm} /$ bird, device for claw shortening.

Enriched cage housing system (EE) according to Council Directive 99/74/EC - three-floor, total area $945 \mathrm{~cm}^{2} /$ bird ( 8 birds kept on an area of $7560 \mathrm{~cm}^{2}-180 \times 42 \times 45 \mathrm{~cm}$ ), available area $643 \mathrm{~cm}^{2} /$ bird, 6 nipple drinkers, belt feeder $20 \mathrm{~cm} /$ bird, nest $(30 \times 35 \times 45 \mathrm{~cm})$, perching area $15 \mathrm{~cm} /$ bird, devices for dustbathing and scratching, device for claw shortening,

Deep litter housing system (DL) - available area $2000 \mathrm{~cm}^{2} /$ bird $\left(20\right.$ birds kept on an area of $40000 \mathrm{~cm}^{2}-200$ $\times 200 \times 180 \mathrm{~cm}$ ), tube feeder $5 \mathrm{~cm} /$ bird, round drinker $2 \mathrm{~cm} /$ bird, deep litter made of wood shavings.

All of the housing technologies were situated in the same building with central system of ventilation and temperature regulation. For each technology, experimental group consisting of 12 birds were established with the mean body weight of $1,300 \pm 50 \mathrm{~g}$. Throughout the study, the hens were fed a complete diet for laying hens containing $875 \mathrm{~g} \cdot \mathrm{kg}^{-1}$ of dry matter, energy content $\mathrm{ME}_{\mathrm{N}} 11.1 \mathrm{MJ} \cdot \mathrm{kg}^{-1}$, content of nitrogen substances $170.7 \mathrm{~g} \cdot \mathrm{kg}^{-1}$, Ca $35.9 \mathrm{~g} \cdot \mathrm{kg}^{-1}$ and P $6.3 \mathrm{~g} \cdot \mathrm{kg}^{-1}$. A constant light-dark (L: D) cycle (15: 9, switching on at $4.00 \mathrm{~h}$, switching off at $19.00 \mathrm{~h}$ ) was maintained in all three technologies as recommended in technological instructions for ISA BROWN hens. The temperature of housing was in the range from 18 to $22{ }^{\circ} \mathrm{C}$; relative humidity ranged from 65 to $70 \%$. No red mite and other parasite or viral infection was found during experimental period. Local Ethics Committee approved the experimental protocol.

Collection of blood samples

Blood samples $(5 \mathrm{ml})$ of all hens in experimental groups were collected from the brachial vein of hens at the age of 22, 47 and 75 weeks, always between 07:00 and 08:30 h. Heparin was used as anticoagulant. Two $\mathrm{ml}$ of blood of all samples were centrifuged and the separated plasma was stored at $-20^{\circ} \mathrm{C}$ until analyzed. Three $\mathrm{ml}$ of whole blood were used for Se analysis. Blood sampling was performed randomly in hens kept in standard, enriched and deep litter technology.

Biochemical indicators

In blood plasma the following elements were measured: calcium $(\mathrm{Ca})$, phosphorus $(\mathrm{P})$, magnesium $(\mathrm{Mg})$, potassium $(\mathrm{K})$, zinc $(\mathrm{Zn})$, and copper $(\mathrm{Cu})$; selenium concentration $(\mathrm{Se})$ was measured in whole blood. The minerals were analyzed with commercially available kits Bio-La-Tests made by Pliva-Lachema, Inc., Czech Republic, with COBAS MIRA S (Roche, $\mathrm{CH}$ ). Selenium concentration was analysed by atomic absorption spectrometry (AAS). Samples of whole heparinised blood were mineralized in a closed system using a microwave (MLS-1200, Milestone, Italy) digestion technique with $\mathrm{HNO}_{3}$ and $\mathrm{H}_{2} \mathrm{O}_{2}$. Samples were evaporated and the mineral residue was dissolved in water to which $20 \% \mathrm{HCl}$ was added. Selenium was then determined with Solar $939 \mathrm{AA}$ Spectrometer (Unicam, UK) using a hydride AAS technique.

Determination of the eggshell quality

Eggs of average size were selected on days of blood collection for the respective technologies (eggs that were too big or too small and eggs with damaged or absent eggshell were not included in the analysis). The eggs were marked with a pencil; group designation and serial number were written on each egg to avoid confusion. The eggs were analyzed immediately after the collection. Eggshells were weighed with an accuracy of $0.1 \mathrm{~g}$ with laboratory scales after washing with warm water and drying at room temperature for one week (egg membranes were not removed). The eggshell strength $\left(\mathrm{N} / \mathrm{cm}^{2}\right)$ was determined using the Egg Crusher EGC (VEIT Electronic, CZ). Eggshell thickness ( $\mathrm{mm}$ ) is expressed as an average value measured by Digimatic Outside Micrometer (Mitutoyo, JPN) at both poles and in the equator of the egg.

Statistical evaluation

The data are expressed as means \pm SEM. Changes in minerals were analyzed by repeated measures ANOVA for factors housing technology as independent variable and age of hens as dependent variable. Egg quality was analyzed by two-way ANOVA for factors housing technology as independent variable and age of hens as dependent variable. ANOVA was followed by post-hoc Fisher's LSD test for pairwise comparisons, where appropriate. All statistical analyses were performed by the Statistica 7.0 statistical software (StatSoft Inc., Tulsa, USA). The overall level of significance was defined as $p<0.05$. 


\section{Results}

Plasma calcium significantly increased from the beginning to the end of the experiment $(\mathrm{F}(2,66)=12.616, p<0.001)$ in all housing systems (Fig. 1). At 22 weeks of age, the highest plasma calcium concentrations were found in the birds housed on deep litter floor, whereas at 47 weeks of age this housing system provided the lowest plasma calcium levels. At 47 weeks of age a significantly higher feed intake was found in the DL group (145.6 $\mathrm{g} \cdot$ bird $^{-1} \cdot$ day $^{-1}$ vs. S $-119.1 \mathrm{~g} \cdot$ bird $^{-1} \cdot$ day $^{-1}$ and EE $-123.3 \mathrm{~g} \cdot$ bird $^{-1} \cdot$ day $\left.^{-1}\right)$. No differences in plasma $\mathrm{Ca}$ concentrations, feed intake and daily eggshell production were found between the groups S and EE (Table 1), particularly at 47 weeks of age. At the end of experiment, the lowest $\mathrm{Ca}$ concentrations were found in laying hens housed in enriched housing system. No significant differences in calcium concentrations were found between the housing systems. The lowest eggshell production was found in the DL group in all the periods evaluated (Table 1).

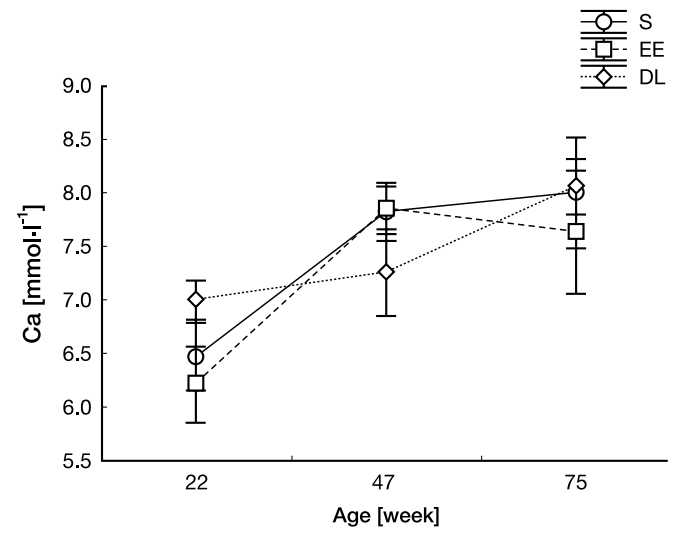

Fig. 1. Plasma calcium concentrations in laying hens kept in traditional $(\mathrm{S}, \mathrm{n}=12)$, enriched $(\mathrm{EE}, \mathrm{n}=12)$ and deep litter $(\mathrm{DL}, \mathrm{n}=12$ ) housing system during experimental period. Data represent mean $\pm \mathrm{SEM}$.

Table 1. Egg shell production and feed intake of hens in traditional $(\mathrm{S}, \mathrm{n}=12)$, enriched $(\mathrm{EE}, \mathrm{n}=12)$ and deep litter $(\mathrm{DL}, \mathrm{n}=12)$ housing system during experimental period

\begin{tabular}{|l|c|c|c|c|}
\hline & Technology & week 22 & week 47 & week 75 \\
\hline $\begin{array}{l}\text { Egg shell } \\
\text { production } \\
\left(\mathrm{g} \cdot \text { hen }^{-1} \cdot \text { day }^{-1}\right)\end{array}$ & S & 5.14 & 5.81 & 4.60 \\
\cline { 2 - 5 } & EE & 5.25 & 5.78 & 4.83 \\
\hline $\begin{array}{l}\text { Feed } \\
\text { intake } \\
\left(\mathrm{g} \cdot \text { hen }^{-1} \cdot \text { day }^{-1}\right)\end{array}$ & S & 3.89 & 4.66 & 2.22 \\
\cline { 2 - 5 } & EE & 117.3 & 119.1 & 111.5 \\
\cline { 2 - 5 } & DL & 126.2 & 123.3 & 115.5 \\
\hline
\end{tabular}

Eggshell breaking strength (Table 2) significantly decreased with the age of birds $(\mathrm{F}(2,66)=$ 93.041, $p<0.001)$. A significant influence of housing system on eggshell strength was detected $(\mathrm{F}(4,66)=3.302, p<0.05)$. The eggshell strength was lower ( $p$ $<0.05)$ in the group $\mathrm{S}$ compared to EE at 22 weeks of age. Also eggshell production at 22 weeks of age was lower for $\mathrm{S}$, and higher plasma Ca content was observed in this group. At 75 weeks of age, a higher eggshell strength was found in the birds housed in the traditional $(p<0.05)$ and enriched $(p<0.01)$ cages compared to those housed on deep litter.

Age had an effect on eggshell weight $(\mathrm{F}(2,66)=63.042, p<0.001)$. For traditional cages, eggshell weight gradually increased throughout the experiment, although an increase $(p<0.01)$ was confirmed only for the period from 22 to 47 weeks of age (Table 2$)$. For the enriched cages and deep litter, an increase $(p<0.01)$ was observed from the beginning of the $47^{\text {th }}$ week of age, and was followed by a decrease till the end of the experiment. 
Table 2. Qualitative indicators of egg shell of hens in traditional $(\mathrm{S}, \mathrm{n}=12)$, enriched $(\mathrm{EE}, \mathrm{n}=12)$ and deep litter $(\mathrm{DL}, \mathrm{n}=12$ ) housing system during experimental period. Superscripts $(\mathrm{a}, \mathrm{b})$ represent significant differences between the groups at $p<0.05$.

\begin{tabular}{|l|c|c|c|c|c|}
\hline & Technology & $\mathrm{n}$ & week $22 \quad p$ & week $47 \quad p$ & week $75 \quad p$ \\
\hline \multirow{3}{*}{$\begin{array}{l}\text { Shell breaking } \\
\text { strength }\left(\mathrm{N} \cdot \mathrm{cm}^{-2}\right)\end{array}$} & $\mathrm{S}$ & 12 & $38.78 \pm 1.21^{\mathrm{a}}$ & $33.97 \pm 0.81$ & $25.76 \pm 0.94^{\mathrm{a}}$ \\
\cline { 2 - 6 } & $\mathrm{EE}$ & 12 & $44.83 \pm 1.56^{\mathrm{b}}$ & $34.73 \pm 1.74$ & $27.50 \pm 1.61^{\mathrm{a}}$ \\
\cline { 2 - 6 } & $\mathrm{DL}$ & 12 & $42.74 \pm 1.98^{\mathrm{ab}}$ & $35.17 \pm 1.69$ & $20.38 \pm 2.12^{\mathrm{b}}$ \\
\hline \multirow{3}{*}{$\begin{array}{l}\text { Shell thickness } \\
(\mathrm{mm})\end{array}$} & $\mathrm{S}$ & 12 & $0.411 \pm 0.003$ & $0.403 \pm 0.003^{\mathrm{a}}$ & $0.325 \pm 0.005^{\mathrm{a}}$ \\
\cline { 2 - 6 } & $\mathrm{EE}$ & 12 & $0.417 \pm 0.007$ & $0.417 \pm 0.004^{\mathrm{b}}$ & $0.343 \pm 0.009^{\mathrm{a}}$ \\
\cline { 2 - 6 } & $\mathrm{DL}$ & 12 & $0.405 \pm 0.006$ & $0.407 \pm 0.005^{\mathrm{ab}}$ & $0.378 \pm 0.009^{\mathrm{b}}$ \\
\hline \multirow{3}{*}{\begin{tabular}{l} 
Shell weight $(\mathrm{g})$ \\
\cline { 2 - 6 }
\end{tabular}} & $\mathrm{S}$ & 12 & $5.97 \pm 0.063$ & $6.31 \pm 0.061^{\mathrm{a}}$ & $6.38 \pm 0.073$ \\
\cline { 2 - 6 } & $\mathrm{EE}$ & 12 & $6.19 \pm 0.112$ & $6.66 \pm 0.680^{\mathrm{a}}$ & $6.4 \pm 0.145$ \\
\cline { 2 - 6 } & $\mathrm{DL}$ & 12 & $6.00 \pm 0.103$ & $6.61 \pm 0.116^{\mathrm{b}}$ & $6.28 \pm 0.146$ \\
\hline
\end{tabular}

The decrease was significant $(p<0.01)$ only for the deep litter technology. Effects of housing technology on eggshell weight were also confirmed $(\mathrm{F}(4,66)=3.705, p<0.05)$. At 47 weeks of age, higher values were found for deep litter $(p<0.05)$ and enriched cages $(p<0.01)$ compared to traditional cages. Egg weight was also higher deep liter and enriched cages (EE, DL) than for the technology $\mathrm{S}$.

The housing system had no effect on blood plasma phosphorus concentrations. Plasma phosphorus concentrations were decreasing in all the housing systems from the beginning to the end of the experiment (Fig. 2). During the laying period significant changes in factor time were found $(\mathrm{F}(2,66)=30.051, p<0.001)$. Fisher's post hoc test showed a decrease $(p<0.01)$ in week 22 for cage systems.

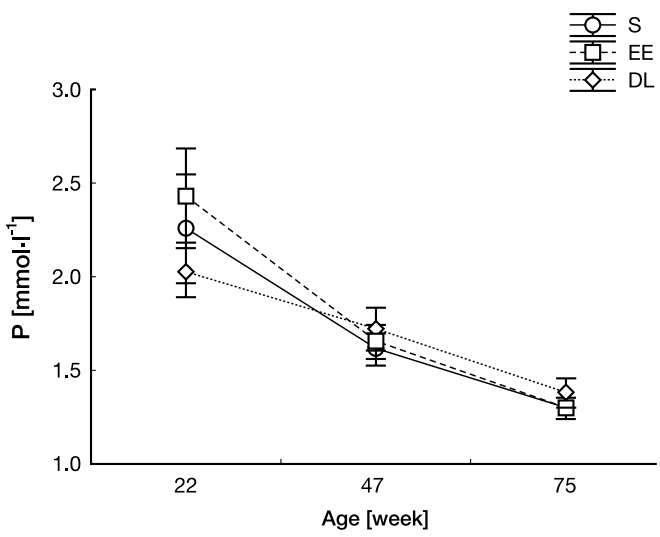

Fig. 2. Plasma phosphorus concentrations in laying hens kept in traditional $(S, n=12)$, enriched $(E E, n=12)$ and deep litter $(\mathrm{DL}, \mathrm{n}=12$ ) housing system during experimental period. Data represent mean $\pm \mathrm{SEM}$.

The age had a significant effect on potassium concentrations $(\mathrm{F}(2,66)=6.036$, $p<0.01)$. Potassium levels were increasing from the beginning of the experimental period to 47 weeks of age for all the housing systems (Fig. 3). A decrease $(p<0.05)$ followed again till 75 weeks of age for the enriched cages and deep litter. Only for the traditional cages plasma potassium levels were increasing till the end of the experimental period. The housing system also affected blood plasma potassium concentrations $(F(2,33)=5.341$, $p<0.01)$. The lowest concentration $(p<0.05)$ was found for deep litter at 22 weeks of age 


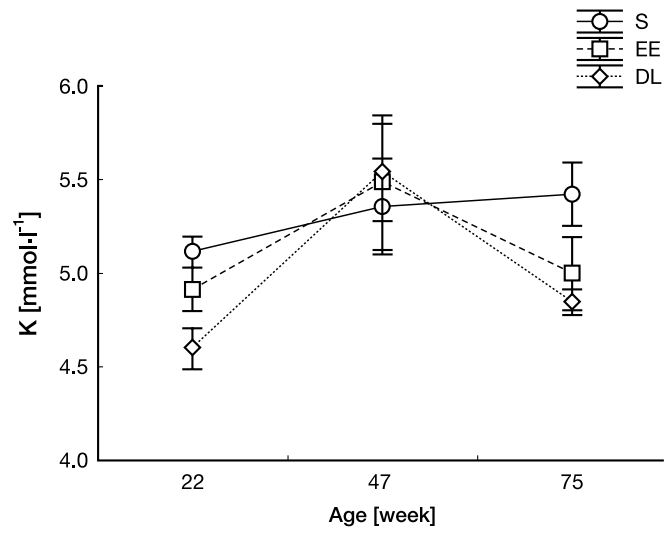

Fig. 3. Plasma potassium concentrations in laying hens kept in traditional $(S, n=12)$, enriched $(E E, n=12)$ and deep litter $(\mathrm{DL}, \mathrm{n}=12$ ) housing system during experimental period. Data represent mean $\pm \mathrm{SEM}$.

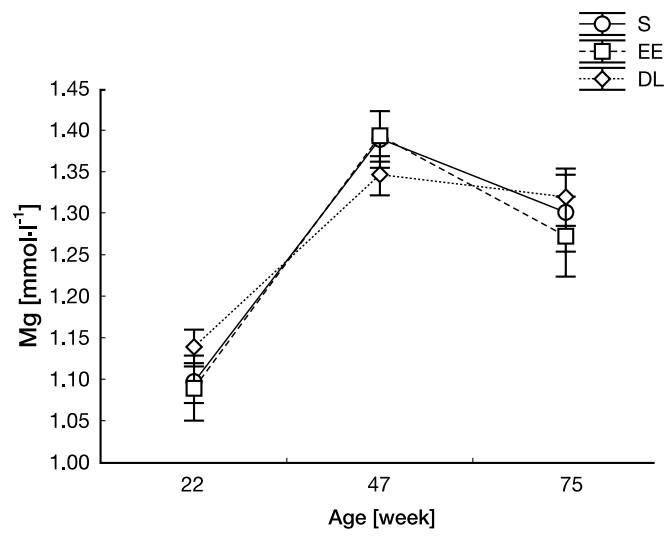

Fig. 4. Plasma magnesium concentrations in laying hens kept in traditional $(S, n=12)$, enriched $(E E, n=12)$ and deep litter $(\mathrm{DL}, \mathrm{n}=12)$ housing system during experimental period. Data represent mean $\pm \mathrm{SEM}$.

of birds. A significant difference $(p<0.05)$ was also found at 75 weeks of age between the traditional cages and deep litter.

The housing system was found to have no influence on blood plasma magnesium levels in laying hens (Fig. 4). On given dates the values for the different housing systems showed no marked differences. Differences were found for factor time $(\mathrm{P}(2,66)=44.972, p<$ $0.001)$. Magnesium levels significantly increased from the beginning of the experiment to 47 weeks of age $(p<0.01)$ for all the housing systems. The subsequent decrease of mean values at 75 weeks of age in all the groups was not significant.

A similar tendency was observed in plasma zinc levels (Fig. 5). An effect was found again in the age of laying hens $(\mathrm{P}(2,66)=38.948, p<0.001)$. Plasma zinc levels increased from the beginning of the experiment to 47 weeks of age $(p<0.01)$ in all the housing systems, and the increase was followed by a non-significant decrease in mean values at 75 weeks of age in all the groups. The highest values were found for the traditional cages during the entire experimental period, whereas the lowest mean values were found for deep litter. No significant effect of housing systems on plasma zinc levels was found. 


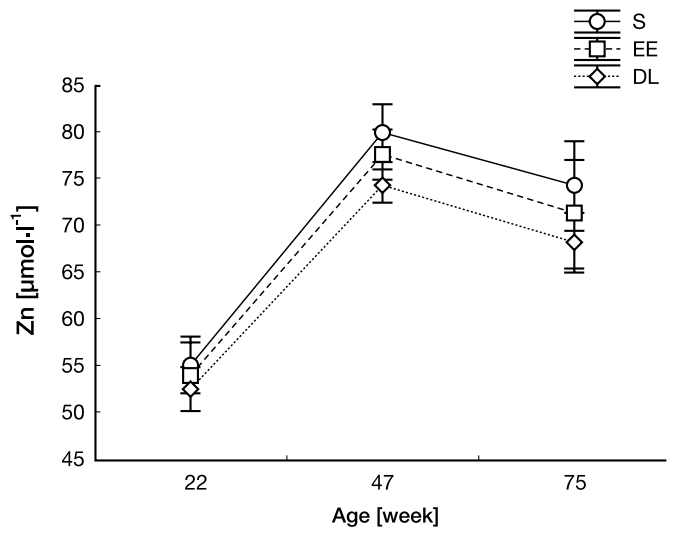

Fig. 5. Plasma zinc concentrations in laying hens kept in traditional $(\mathrm{S}, \mathrm{n}=12)$, enriched $(\mathrm{EE}, \mathrm{n}=12)$ and deep litter ( $\mathrm{DL}, \mathrm{n}=12$ ) housing system during experimental period. Data represent mean $\pm \mathrm{SEM}$.

The age of hens had an effect on blood plasma copper concentrations $(\mathrm{F}(2,66)=6.653$, $p<0.01$ ). Mean values increased in all the housing systems from 22 weeks of age (Fig. $6)$, and the increase was for enriched cages $(p<0.01)$ and deep litter $(p<0.05)$. It was followed by a non-significant decrease in values. The housing system had no effect on plasma copper levels.

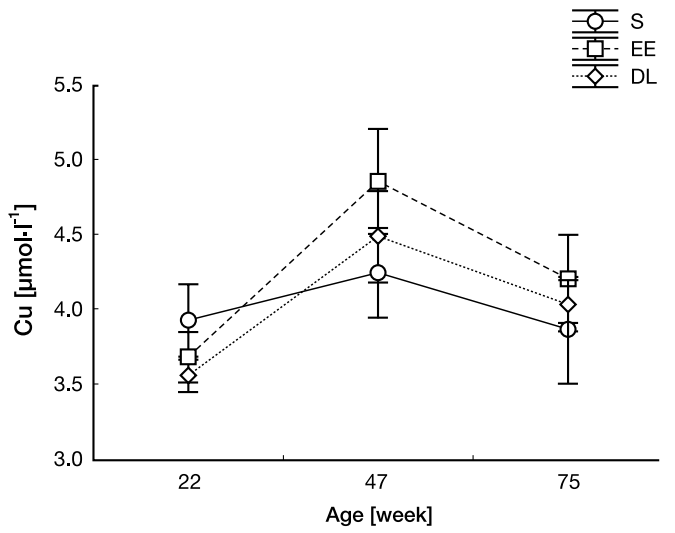

Fig. 6. Plasma copper concentrations in laying hens kept in traditional $(S, n=12)$, enriched $(E E, n=12)$ and deep litter $(\mathrm{DL}, \mathrm{n}=12$ ) housing system during experimental period. Data represent mean $\pm \mathrm{SEM}$.

The highest blood selenium levels in laying hens were determined at the beginning of the experiment at 22 weeks of age (Fig. 7). During the experiment, a decrease was found at 47 weeks of age $(\mathrm{F}(2,66)=131.27, p<0.001)$ and subsequent testing confirmed differences $(p<0.001)$ between all the housing systems. No significant decreases were found until the end of experiment. Housing technology was confirmed to have an effect $(\mathrm{F}(4,66)=3,8.27$, $p<0.05)$ on blood Se levels. Blood selenium levels were found to be higher $(p<0.05)$ in laying hens housed in traditional cages than in those housed in the enriched cages. 


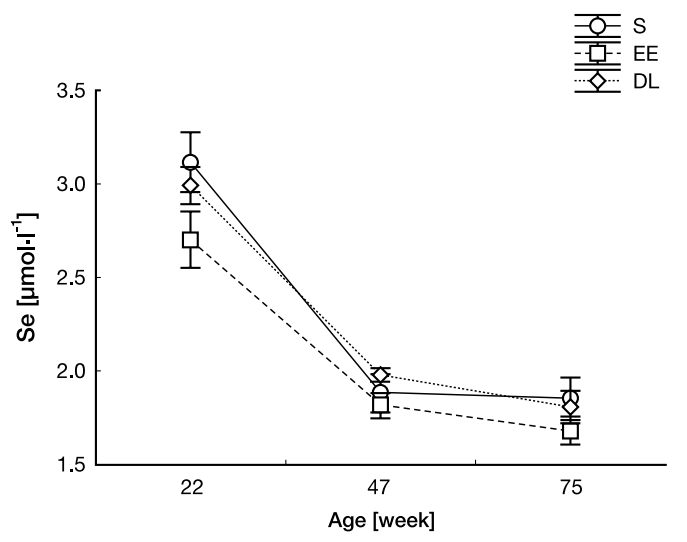

Fig. 7. Plasma selenium concentrations in laying hens kept in traditional $(S, n=12)$, enriched $(E E, n=12)$ and deep litter $(\mathrm{DL}, \mathrm{n}=12$ ) housing system during experimental period. Data represent mean $\pm \mathrm{SEM}$.

\section{Discussion}

None of the blood plasma minerals evaluated, except for potassium, was significantly influenced by the housing systems. This was to a certain extent caused by the uniform diets for all groups of birds under study because dietary levels of macro- and microelements significantly affect plasma mineral levels (Sooncharernying and Edwards 1989; Bain 1992; Petrovič et al. 2006).

A considerable increase in plasma Ca levels at the beginning of laying period and subsequent gradual increase was also observed by Cerolini et al. (1990), Gyenis et al. (2006), Filizciler et al. (2002), and Strakova et al. (1994). On the contrary, Burnham et al. (2003) described an increase in calcium levels before the laying period and a decrease in calcium levels during the laying. Also Eren et al. (2004) reported decreasing plasma calcium levels in laying hens from 22 to 28 weeks of age; however, these changes were not significant. Suchy et al. (2001) and Kurtoglu et al. (2001) reported mean Ca levels similar to the mean values found in our experiment. Our values also fall within the physiological range as described by Belay and Teeter (1996). Lower values as compared with our results were reported by Koelkebeck and Odom (1995), Sahin et al. (2002b), and Eren et al. (2004).

For hens housed in cages, higher eggshell production was found to be associated with lower plasma calcium levels, and vice versa. Increasing plasma $\mathrm{Ca}$ levels were associated with decreasing eggshell strength and thickness. This finding to a certain extent corresponds with the results of Rezac et al. (2000), who determined the highest plasma Ca levels in laying hens producing eggs with damaged shells. On the other hand, Hester et al. (1980) reported that a decrease in blood plasma Ca levels had no significant effect on eggshell quality. Other authors also reported that plasma calcium content does not correlate with eggshell quality (Buss and Stout 1981; Jerabek et al. 1993). Higher plasma Ca levels at 22 weeks of age in DL could have been caused by a potential intake of litter as described by Millan et al. (2003), who found the effect of a diet with higher fibre content on blood chemistry in birds, e.g. increased plasma calcium concentrations. In deep litter technology, the lowest eggshell production was found, but given the free housing the hens could have eaten the eggs which might have biased the result of eggshell production. Feed intake was also very irregular during the experimental period.

The lowest eggshell strength, thickness and weight were found in eggs produced in traditional cage technologies at the beginning and in the middle of the experimental 
period. The highest mean values of these indicators were found in the enriched cages. Bain (1992) in accordance with results of this study reported a thinning of the eggshell with an increasing number of laying hens per area unit. Leyendecker et al. (2002) and Pistekova et al. (2006), unlike other researchers, found no significant differences in eggshell strength between cages and deep litter. These authors reported higher eggshell weight for traditional cages than for deep litter, which does not correspond with this study's results, either.

Mean values of plasma phosphorus in laying hens of all groups decreased from the beginning of the laying cycle to the end at 75 weeks of age, which corresponds with the results of Strakova et al. (1994) and Eren et al. (2004). On the contrary, Filizciler et al. (2002) and Suchy et al. (2004) found a gradual increase in plasma phosphorus levels in laying hens up to 38 weeks of age. Suchý et al. (2004) reported a subsequent decrease of values with varying tendencies. The values we obtained from all the housing systems ranged within mean values reported e.g. by Jerabek et al. (1993), Koelkebeck and Odom (1995), Belay and Teeter (1996), Kaya et al. (2001), Suchy et al. (2001), Sahin et al. (2002a), and Thiemel and Jelinek (2004). Substantially higher values were published by Eren et al. (2004), whereas lower values were reported by Kurtoglu et al. (2001). Boorman and Gunaratne (2001) reported that there is in fact no relationship between plasma phosphorus levels and eggshell weight, which is in accordance with our results given the decrease in plasma $\mathrm{P}$ levels and varying changes in eggshell weight during the laying period.

Despite the varying tendencies, the average values of plasma potassium levels gradually increased from the beginning until 47 weeks of age, which does not correspond with findings of Strakova et al. (1994), who observed a significant reduction in plasma potassium levels during the laying cycle. On the other hand, Koelkebeck and Odom (1995) reported no significant changes in plasma potassium levels under ambient temperature. Mean values similar to those received in this study were reported by Suchy et al. (1989; 2001), Gezen et al. (2005), and Gyenis et al. (2006). Lower mean plasma potassium levels were reported by Koelkebeck and Odom (1995). The results of this experiment correspond to a certain extent with the findings of Strakova et al. (1994), who noted increased magnesium levels during the laying period. Slight changes in plasma potassium levels during the laying period were reported by Eren et al. (2004). Mean values found in this study correspond with the range of values reported for instance by Suchy et al. (2001) and Kurtoglu et al. (2002). Lower values were published by Koelkebeck and Odom (1995), Kurtoglu et al. (2001), and Thiemel and Jelinek (2004).

Filizciler et al. (2002) reported a similar range of plasma $\mathrm{Cu}$ levels compared to our results $\left(3.56-4.86 \mu \mathrm{mol} \cdot \mathrm{l}^{-1}\right)$. Copper levels increased during the experiment from 22 to 47 weeks of age. From 47 to 75 weeks of age, a decrease in plasma $\mathrm{Cu}$ levels was observed in all the housing systems. Also Filizciler et al. (2002) reported increasing plasma copper levels from the beginning of the laying period. Plasma zinc levels considerably increased from 22 to 47 weeks of age in all the housing systems. From 47 weeks of age to the end of the experiment, plasma zinc levels decreased in these technologies. A similar increase in zinc concentration was reported by Jankowski et al. (2003). Opposite tendencies were observed by Filizciler et al. (2002) when evaluating zinc concentrations during the period from 26 to 38 weeks of age. Decreased plasma zinc levels in laying hens in all the housing systems in the second half of the experiment were within the physiological range. Changes in plasma zinc levels during the experimental period were also associated with circulation of vitellogenin in relation to the reproductive status (Mitchell and Carlisle 1991). Kaya et al. (2001) found a positive correlation between plasma zinc concentrations and egg production. These authors reported a range of values similar to the mean values obtained in this experiment. 
Mean blood selenium concentrations in laying hens decreased for all housing systems from the beginning to the end of the experiment. Petrovič et al. (2006) reported mean blood selenium levels in laying hens during the laying period of $1.7 \mu \mathrm{mol} \cdot \mathrm{l}^{-1}$, while the values in this experiment ranged from 1.60 to $3.11 \mu \mathrm{mol} \cdot \mathrm{l}^{-1}$.

The results of this study indicate that the housing systems compared had no significant influence on the blood plasma mineral profile in laying hens and values were within the physiological values. However, the age of laying hens or the phase of the laying cycle had a certain effect on changes in mineral levels. Better qualitative indicators of eggshell were found in most time periods of the laying cycle for the enriched cages. In several cases, these differences were significant.

\section{Minerální profil krevní plazmy a kvalitativní indikátory skořápky u nosnic v různých technologických systémech ustájení}

Cílem práce bylo porovnat ukazatele minerálního profilu krevní plazmy $(\mathrm{Ca}, \mathrm{P}, \mathrm{K}, \mathrm{Mg}$, $\mathrm{Zn}, \mathrm{Cu}$ a $\mathrm{Se}$ ) a kvality skořápky (hmotnost, pevnost a tloušt'ka skořápky) u nosnic ustájených ve třech různých systémech (tradiční klecový systém, obohacený klecový systém a hluboká podestýlka). V každém ze systémů ustájení bylo sledováno 12 nosnic hybridní kombinace ISA Brown v průběhu snáškového cyklu od 22. do 75. týdne věku. Byl zaznamenán průkazný vliv ( $p<0,05$ a $p<0,01)$ věku (fáze snáškového cyklu) na koncentraci všech analyzovaných minerální prvků. Pevnost vaječné skořápky se snižovala $(p<0,001)$ $\mathrm{s}$ věkem zvírat. Na základě dosažených výsledků lze konstatovat, že srovnávané technologie ustájení signifikantně neovlivnily sledované ukazatele minerálního profilu krevní plazmy nosnic a pohybovaly se v rozmezí fyziologických hodnot. Ačkoli byl zaznamenán průkazný vliv technologie ustájení na pevnost a hmotnost skořápky. Nejvyšší kvalita vaječné skořápky byla zaznamenána ve většině případů v obohacené klecové technologii.

\section{Acknowledgements}

This study was supported by the Ministry of Agriculture, National Agency for Agriculture Research (NAZV), Czech Republic, Grant No. QC1128.

\section{References}

Abrahamsson P, Tauson R 1997: Effects of group size on performance health and birds' use of facilities in furnished cages for laying hens. Acta Agric Scand Sect A-Anim Sci 47: 254-260

Abrahamsson P, Tauson R, Appleby MC 1995: Performance of 4 hybrids of laying hens in modified and conventional cages. Acta Agric Scand Sect A-Anim Sci 45: 286-296

Bain MM 1992: Eggshell strength - a relationship between the mechanism of failure and the ultrastructural organization of the mammillary layer. Brit Poultry Sci 33: 303-319

Beisel WR 1982: Single nutrients and immunity. Am J Clin Nutr 35: 417-468

Belay T, Teeter RG 1993: Broiler water-balance and thermobalance during thermoneutral and high ambienttemperature exposure. Poultry Sci 72: 116-124

Belay T, Teeter RG 1996: Virginiamycin and caloric density effects on live performance, blood serum metabolite concentration, and carcass composition of broilers reared in thermoneutral and cycling ambient temperatures. Poultry Sci 75: 1383-1392

Boorman KN, Gunaratne SP 2001: Dietary phosphorus supply, egg-shell deposition and plasma inorganic phosphorus in laying hens. Brit Poultry Sci 42: 81-91

Burnham MR, Peebles ED, Branton SL, Jones MS, Gerard PD 2003: Effects of F-strain Mycoplasma gallisepticum inoculation at twelve weeks of age on the blood characteristics of commercial egg laying hens. Poultry Sci 82: 1397-1402

Buss EG, Stout JT 1981: Shell deposition rates in birds selected for thick and thin eggshell production. Poultry Sci 60: 477-481

Cerolini S, Baldi A, Cavalchini LG 1990: Blood and plasma biochemical variables in laying hens of different strains and ages. Arch Geflugelkd 54: 190-194

Ching CY 1992: Effect of acute heat stress in the blood characteristics of Thaiwan country chickens and broilers. J Chin Soc Anim Sci 21: 57-66

Combs GF, Combs SB 1984: The nutritional biochemistry of selenium. Ann Rev Nutr 4: 257-280 
Cusack M, Fraser AC, Stachel T 2003: Magnesium and phosphorus distribution in the avian eggshell. Comp Biochem Physiol B-Biochem Mol Biol 134: 63-69

Donoghue DJ, Krueger WF, Donoghue AM, Byrd Ja, Ali DH, Elhalawani ME 1990: Magnesium-aspartatehydrochloride reduces weight-loss in heat-stressed laying hens. Poultry Sci 69: 1862-1868

Eren M, Uyanik F, Kucukersan S 2004: The influence of dietary boron supplementation on egg quality and serum calcium, inorganic phosphorus, magnesium levels and alkaline phosphatase activity in laying hens. Res Vet Sci 76: 203-210

Filizciler M, Cerci Ih, Tatli P 2002: Effects of night feeding on SPF (Specific Pathogen Free) white egg layers under heat stress. Turk J Vet Anim Sci 26: 439-446

Gezen SS, Eren M, Deniz G 2005: The effect of different dietary electrolyte balances on eggshell quality in laying hens. Rev Med Vet 156: 491-497

Gyenis J, Suto Z, Romvari R, Horn P 2006: Tracking the development of serum biochemical parameters in two laying hen strains - a comparative study. Arch Tierz-Arch of Anim Breed 49: 593-606

Hester PY, Wilson EK, Pierson FW, Fabijanska I 1980: Plasma inorganic-phosphate, calcium, and magnesium levels of hens which laid soft-shelled or shell-less eggs. Poultry Sci 59: 2336-2341

Jankowski J, Glogowski J, Suszynska D, Polak M, Ciereszko A 2003: Effect of zinc supplemented diets on the reproduction results for turkey-hens. Medycyna Wet 59: 919-921

Jerabek S, Suchy P, Illek J, Strakova E, Zelenka J 1993: Haematological and some biochemical parameters of the blood of hens with damaged and integral shells. Zivocisna Vyroba 38: 145-151

Klasing KC 1998: Comparative Avian Nutrition, Cambridge University Press, Cambridge, pp. 277-299

Kaya S, Umucalilar HD, Haliloglu S, Ipek H 2001: Effect of dietary vitamin A and zinc on egg yield and some blood parameters of laying hens. Turk J Vet Anim Sci 25: 763-769.

Koelkebeck KW, Odom TW 1995: Laying hen responses to acute heat-stress and carbon-dioxide supplementation. 2. Changes in plasma enzymes, metabolites and electrolytes. Comp Biochem Physiol A-Physiol 112: 119-122

Kurtoglu V, Kurtoglu F, Coskun B 2001: Effects of boron supplementation of adequate and inadequate vitamin D3-containing diet on performance and serum biochemical characters of broiler chickens. Res Vet Sci 71: 183-187

Kurtoglu V, Kurtoglu F, Coskun B, Seker E, Balevi T, Cetingul Is 2002: Effects of boron supplementation on performance and some serum biochemical parameters in laying hens. Rev Med Vet 153: 823-828

Leach RM, Gross JR 1983: The effect of manganese deficiency upon the ultrastructure of the eggshell. Poultry Sci 62: 499-504

Ledvinka Z, Tumova E, Arent E, Holoubek J, Klesalova L 2000: Egg shell quality in some white-egged and brown-egged cross combinations of dominant hens. Czech J Anim Sci 45: 285-288

Leyendecker M, Hamann H, Hartung J, Glunder G, Nogossek N, Neumann U, Surie C, Kamphues J, Distl O 2002: Analysis of the egg shell stability and the bone strength of laying hens in three different hen housing systems. Zuchtungskunde 74: 144-155

Millan J, Gortazar C, Buenestado FJ, Rodriguez P, Tortosa FS, Villafuerte R 2003: Effects of a fiber-rich diet on physiology and survival of farm-reared red-legged partridges (Alectoris rufa) Comp Biochem Physiol A-Mol Integr Physiol 134: 87-93

Mitchell MA, Carlisle AJ 1991: Plasma zinc as an index of vitellogenin production and reproductive status in the domestic fowl. Comp Biochem Physiol A- Mol Integr Physiol 100: 719-724

Petrovic V, Boldizarova K, Faix S, Mellen M, Arpasova H, Leng L 2006: Antioxidant and selenium status of laying hens fed with diets supplemented with selenite or Se-yeast. J Anim Feed Sci 15: 435-444

Pistekova V, Hovorka M, Vecerek V, Strakova E, Suchy P 2006. The quality comparison of eggs laid by laying hens kept in battery cages and in a deep litter system. Czech J Anim Sci 51: 318-325

Rezac P, Poschl M, Havlicek Z 2000: Relationship of plasma oestradiol-17 beta and cholesterol levels to eggshell strength in laying hens. Czech J Anim Sci 45: 313-317

Sahin K, Kucuk O 2001: A simple way to reduce heat stress in laying hens as judged by egg laying, body weight gain and biochemical parameters. Acta Vet Hung 49: 421-430

Sahin K, Kucuk N, Sahin N, Gursu MF 2002a: Optimal dietary concentration of vitamin E for alleviating the effect of heat stress on performance thyroid status, ACTH and some serum metabolite and mineral concentrations in broilers. Vet Med-Czech 47: 110-116

Sahin K, Kucuk O, Sahin N, Sari M 2002b: Effects of vitamin C and vitamin E on lipid peroxidation status, some serum hormone, metabolite, and mineral concentrations of Japanese quail reared under heat stress $\left(34^{\circ} \mathrm{C}\right)$. Int J Vitam Nutr Res 71: 91-100

Siegel HS 1995: Stress, strains and resistance. Brit Poultry Sci 36: 3-22

Simons PCM 1976: Egg-shell structure. Poultry Sci 55: 2092-2092

Sooncharernying S, Edwards HM 1989: Effect of dietary calcium and phosphorus levels on ultra-filterable calcium and dialyzable phosphorus in the laying hen. Poultry Sci 68: 719-723

Strakova E, Suchy P, Klecker D, Illek J 1994: Hematological and biochemical indicators of the blood in Japanese quail during nursing and laying periods. Zivocisna Vyroba, 39: 409-420

Suchy P, Strakova E, Jarka B, Thiemel J, Vecerek V 2004: Differences between metabolic profiles of egg-type and meat-type hybrid hens. Czech J Anim Sci 49: 323-328 
Suchy P, Strakova E, Vecerek V, Sterc P 2001: Biochemical studies of blood in hens during the laying period. Czech J Anim Sci 46: 383-387

Suchy P, Jerabek S, Stanek S, Zelenka J 1989: Dynamics of changes in the blood picture and biochemical indicators of blood plasma in breeder cocks during the period of sexual maturation. Zivocisna Vyroba 34: 741-750

Thiemel J, Jelinek P 2004: The effect of carnitine on hatching rate and metabolic profile of blood in breeding layers. Czech J Anim Sci 49: 517-523

Tufft LS, Nockels CF 1991: The effects of stress, Escherichia coli, dietary ethylenediaminetetraacetic acid, and their interaction on tissue trace-elements in chicks. Poult Sci 70: 2439-2449

Vecerek V, Strakova E, Suchy P, Voslarova E 2002: Influence of high environmental temperature on production and haematological and biochemical indexes in broiler chickens. Czech J Anim Sci 47: 176-182

Wall H, Tauson R 2002: Egg quality in furnished cages for laying hens - Effects of crack reduction measures and hybrid. Poultry Sci 81: 340-348

Wedral EM, Vadehra DV, Baker RC 1974: Chemical composition of cuticle, and inner and outer shell membranes from eggs of Gallus gallus. Comp Biochem Physiol 47: 631-640

Zralý Z, Písaříková B, Trčková M, Navrátilová M 2008: Effect of humic acids on lead accumulation in chicken organs and muscles. Acta Vet Brno 77: 439-445 